\title{
Flesh characteristics of pan-size triploid and diploid rainbow trout (Oncorhynchus mykiss) reared in a commercial fish farm
}

\begin{abstract}
Sexual maturation of rainbow trout during production has a negative effect on the slaughter yields and flesh quality. Induction of triploidy is a method to prevent the development of fertile trout. In many investigations sexually mature triploid and diploid rainbow trout had been compared. In the present study the slaughter characteristics and flesh quality of female immature diploid and triploid rainbow trout reared up to 66 and 75 weeks (pan-size-format) were compared. Considering the age the old fish had significantly higher body and fillet weights accompanied with larger muscle fibres. The fillets of the old trout were brighter and redder, had a reduced water-holding capacity (WHC) and contained more fat and protein. With regard to the ploidy status the triploid trout had higher body and fillet weights and larger muscle fibres. The fillets of the triploid fish were brighter, had a reduced WHC and lower fat contents. With regard to the age-ploidy status interaction the young and old triploid trout had better growth characteristics but the WHC and the fillet fat concentration was reduced in these animals. The colour values were inconsistent. The $\mathrm{pH}$ and electrical conductivity values indicated no higher pre- or peri-mortal stress and/or different stress susceptibility of the investigated young as well as old triploid and diploid trout. In conclusion, it could be suggested that induction of triploidy positively influences body and fillet development mainly by muscle fibre hypertrophy, but the triploid fillets showed slightly worse flesh characteristics (Brightness, WHC).
\end{abstract}

Key Words: rainbow trout, triploid, diploid, flesh quality, muscle structure

\section{Zusammenfassung}

Titel der Arbeit: Fleischeigenschaften von triploiden und diploiden Portions-Regenbogenforellen (Oncorrhynchus mykiss) gemästet in einer kommerziellen Fischfarm

Die sexuelle Reifung von Regenbogenforellen während der Produktion hat einen negativen Einfluss auf die Schlachtausbeuten und die Fleischqualität. Die Triploidie-Induktion ist eine Methode die Entwicklung von fertilen Forellen zu verhindern. In vielen Untersuchungen wurden sexuell reife triploide und diploide Regenbogenforellen verglichen. In der vorliegenden Studie wurden die Schlachteigenschaften und die Fleischqualität von weiblichen, unreifen diploiden und triploiden Regenbogenforellen - gemästet bis zur 66. und 75. Woche (Portionsgröße) - verglichen. Berücksichtigt man das Alter hatten die alten Fische signifikant höhere Körper- und Filetgewichte verbunden mit größeren Muskelfasern. Die Filets der älteren Forellen waren heller und roter, hatten ein reduziertes Wasserbindungsvermögen (WBV) and enthielten mehr Fett und Protein. In Bezug auf den Ploidie-Status hatten die triploiden Forellen höhere Körper- und Filetgewichte und größere Muskelfasern. Die Filets der triploiden Fische waren heller, hatten eine reduziertes WBV und geringere Fettgehalte. Berücksichtigt man die Interaktion zwischen Alter und Ploidie-Status, so hatten die jungen und die alten triploiden Forellen bessere Wachstumseigenschaften, wobei allerdings das WBV und der Fettgehalt des Filets in diesen Tieren reduziert war. Die Farbwerte waren uneinheitlich. Die pH- und Leitfähigkeitswerte gaben keinen Hinweis auf höheren prä- und perimortalen Stress und/oder unterschiedliche Streßempfindlichkeit der untersuchten jungen genauso wie alten triploiden und diploiden Forellen. Zusammenfassend kann gefolgert werden, dass die Triploidie-Induktion die Körper- und Filetentwicklung hauptsächlich durch Muskelfaserhypertrophie beeinflusst, aber dass die triploiden Filets geringgradig schlechtere Fleischeigenschaften (Helligkeit, WBV) zeigten. 


\section{Introduction}

Rainbow trout (Oncorhynchus mykiss) belong taxonomically to the family of the salmonidae together with other species like the Atlantic salmon (Salmo salar) or brown trout (Salmo trutta). It is one of the most important fish species in aquaculture. Rainbow trout are mainly sold at the age of one to two years and a weight of 250 to $400 \mathrm{~g}$ usually after being smoked. In the retail complete fishes or the fillets - packed in portions of 150 or $200 \mathrm{~g}$ - are provided. Rainbow trout of this weight are also called pan-size or portion fishes. At this age most of the trout are immature and this is important for the fish farmer because maturation in rainbow trout reduces the feed conversion and growth rate and additionally has a negative effect on the meat quality and disease resistance of the animals (LINCOLN and BYE, 1984; TIWARY et al., 2004; KIESSLING et al., 2006). Sometimes male rainbow trout show signs of maturation during the second year of production. To overcome maturation-related disadvantages during the production of pan-size rainbow trout the fish farmer could kill and sell the trout before sexual maturity. However, this is a less acceptable solution because the growth of fishes has to be controlled more intensively and the farmer could not produce heavier animals to satisfy other market requirements (LINCOLN et al., 1974). A better solution would be the production of all-female animals to react more flexible to market requirements and reduce the working costs without maturation-related disadvantages. One method to produce all-female offspring is the masculinisation or sex reversal of female trout by application of methyltestosterone during the period of sex differentiation. The XX-sperms of this fish are used to fertilize untreated female trout resulting usually in $100 \%$ female progeny (HUNTER et al., 1983). Another method to induce gynogenesis is the application of sexual hormones (e.g. estradiol) to juvenile fishes (HUNTER AND DONALDSON, 1983; THORGAARD, 1992). The hormonal methods are quite problematic because the use of hormones in animal production is not only less accepted by the consumers, but also strictly regulated by authorities e.g. in the European Community. The femalisation could also be induced by a two step treatment of the gametes. First the gametes are exposed to UV-radiation to destroy the sperms (gynogenesis) and after that the oocytes are treated with high temperatures to produce diploid oocytes (CHOURROUT, 1984; QUILLET, 1994). Maturation-related disadvantages in aquaculture could be also prevented by induction of sterility. An additional advantage of sterile trout is that the animals could be reared to weights at which all-female production is ineffective due to the maturation of the female animals. Triploidisation of the fish genome e.g. by heat or pressure treatment of the oocytes during meiosis is a common method to induce sterility in rainbow trout. The polyploid fish show a reduction in the gonadal development (TIWARY et al., 2004; MUELLER-BELECKE et al., 2006). However, as male triploid rainbow trout which are functionally sterile show considerable gonad development and develop secondary sexual characteristics, the production of all-female triploid populations is most desirable to reduce any sexual-related disadvantages (LINCOLN and SCOTT, 1983; THORGAARD, 1992). Several investigations showed that growth and survival of triploid rainbow trout were comparable between the diploid and triploid fishes before start of maturation (SURESH and SHEEHAN, 1998; TEUSCHER et al., 2003; MUELLER-BELECKE et al., 2006). However, the flesh characteristics of the rainbow trout fillets - an important 
feature for the consumers - received less attention until now (BJOERNEVIK et al., 2004).

The aim of the present study was to characterize the muscle structure and composition as well as the flesh quality of female triploid and diploid rainbow trout before start of maturation. The fish were collected at two points of time to investigate the trout at the beginning and at the end of the regular marketing period of pan-size format.

\section{Materials and Methods \\ Fish husbandry conditions}

Female diploid (D) and triploid (T) rainbow trout eggs of a Steelhead strain were obtained from a US breeding company. In a rearing farm the eye-point-eggs were incubated and the hatched larvae were subsequently reared up to 34 weeks after fertilization to a weight of ca. $5 \mathrm{~g}$. After transfer of these larvae to a commercial fish farm the triploid and diploid trout grew up separately in long stream basins (initial stocking density approx. $0.42 \mathrm{~kg} / \mathrm{m}^{3}$ water) up to week 66 and 75 after fertilisation.

In the basins the larvae were provided during the complete experiment with clean, oxygenated water. The water had a flow rate of $4-5 \mathrm{l} / \mathrm{s}$, a temperature of $9.0 \pm 1.0^{\circ} \mathrm{C}$ and a $\mathrm{pH}$-value of 7.0 . The oxygen concentration was adjusted to $8-10 \mathrm{mg} / \mathrm{l}$ by flushing the basin with pure oxygen.

The fishes were fed daily with a commercial trout diet (46 \% protein, $24 \%$ fat, $9.6 \%$ crude fibre, $1.9 \%$ ash) considering the specifications of the feed producing company and the actual fish mass. The daily diet portion was distributed to the fish within a period of 6.5 hours. Every 14 min a propeller spread the feed for $20 \mathrm{~s}$ to the water surface. From week 62 up to the slaughter dates at week 66 and 75 the regular trout diet was supplemented with astaxanthin at a concentration of $75 \mathrm{mg} / \mathrm{kg}$ feed.

\section{Sampling of the fillets}

The first 80 triploid (T) and diploid (D) trout ( $N=40$ per genetic group) were slaughtered 66 weeks after fertilisation (T66, D66) - usually the beginning point of the marketing period. Further 80 diploid and triploid fishes $(\mathrm{N}=40$ per genetic group) were slaughtered at week 75 (T75; D75).

At the slaughter day the rainbow trout were transported for approximately $2 \mathrm{~h}$ to the Institute for Animal Breeding and Genetics of the Georg-August University Goettingen. After a recovery time of more than 30 min the animals were stunned by a blow to the head. The weight and length of the body was determined. Subsequently, a small tissue sample was collected from the left gill for the analysis of the ploidy status of the rainbow trout.

After evisceration of the carcasses the gonads and fillets were removed and weighed. The left fillets were used for the $\mathrm{pH}$, electrical conductivity (EC) and colour analysis and for the sample collection.

5 min after slaughter the $\mathrm{pH}_{1-}, \mathrm{EC}_{1^{-}}$and colour values $\left(\mathrm{L}^{*} \mathrm{a}^{*} \mathrm{~b}^{*}\right)$ were determined below the dorsal fin. Then the fillets were chilled and after $3 \mathrm{~h}$ the $\mathrm{pH}_{3}-$ and $\mathrm{EC}_{3^{-}}$ values were determined again below the dorsal fin.

$3 \mathrm{~h}$ after slaughter tissue sample blocks $\left(1 \times 1 \times 1 \mathrm{~cm}^{3}\right)$ were carefully cut from the left fillet either below the dorsal fin, or at the pelvic fin region (mid line) for the histological analysis of the muscle fibres. These histological samples were frozen in liquid nitrogen and stored in cryotubes at $-80^{\circ} \mathrm{C}$ until analysis. 
A small sample $(0.2 \mathrm{~g})$ was removed from the area ventral of the dorsal fin for the determination of the water holding capacity (WHC) of the flesh.

The remaining fillet parts and the right fillets were homogenized, portioned into plastic bags and frozen at $-20^{\circ} \mathrm{C}$ until nutrient analysis.

\section{Analytical methods}

For the analysis of the ploidy status of the rainbow trout the gill tissue was stained with silver nitrate and the nucleoli per cell of 50 cells were counted (PHILLIPS et al., 1986).

The $\mathrm{pH}$ - and EC-values were measured with the pH-Star and LF-Star (Matthäus, Germany). The Minolta CR 300 apparatus (Minolta, Japan) was used for the determination of the colour values ( $\mathrm{L}^{*} \mathrm{a} * \mathrm{~b} *$ ).

The samples for the histological analysis of the muscle tissue were cut in $12 \mu \mathrm{m}$-slices using a cryomicrotome (Leica, Germany). The muscle fibres were visualized with the combined SDH-ATPase staining after basic preincubation ( $\mathrm{pH}$ 10.2) (JOHNSTON et al., 1975; GEYIKOGLU et al., 2004). The slides were investigated with a microscope (Nikon, Germany). After transferring three sectors of the slices to a computer the diameters of 100 muscle fibres per sector were determined using the software LUCIA G (Nikon, Japan).

For the determination of the water-holding-capacity (WHC) $0.2 \mathrm{~g}$ of the fillet was transferred to a filter paper and pressed between two plastic plates in a standardized apparatus for 3 min (MEYER et al., 1984). The Q-value was calculated after determination of the flesh (f) and outer liquid area (F) as follows:

$\mathbf{Q}=\mathbf{f} / \mathbf{F}$

Low Q-values reflect a reduced WHC of the tissue due to the higher amount of squeezed liquid.

The frozen and portioned homogenates of the fillets were used for chemical analysis of the dry matter, fat, ash and crude protein according to the AOAC (1984). The dry matter was determined gravimetrically after drying the homogenate for $24 \mathrm{~h}$ at $105^{\circ} \mathrm{C}$. Fat was analysed after acid hydrolysis and petroleum benzine extraction. For the determination of the ash content the flesh sample was weighed, burned at $600^{\circ} \mathrm{C}$, dried at $105^{\circ} \mathrm{C}$ and reweighed again. Nitrogen was determined after combustion in a Nitrogen Analyser (VarioMax CN, Elementar, Germany) and converted to crude protein by assuming a protein nitrogen content of $16 \%$.

\section{Statistical analysis}

The analysis of the data was performed with the statistical software package Statistica (StatSoft, 2005) using the two-way ANOVA and the following statistical model:

$\mathbf{y}_{\mathrm{ijk}}=\boldsymbol{\mu}+\mathbf{A}_{\mathbf{i}}+\mathbf{P}_{\mathbf{j}}+\mathbf{A P}_{\mathbf{k}}+\mathbf{e}_{\mathrm{ijk}}$

$A_{i}=$ Age ( $i=66,75$ weeks); $P_{j}=$ Ploidy status $(j=$ diploid, triploid $)$; $\mathrm{AP}_{\mathbf{k}}=$ interaction age $\mathrm{x}$ ploidy status $(\mathrm{k}=\mathrm{T66}, \mathrm{D66} ; \mathrm{T75}, \mathrm{D75})$

Significant differences were calculated with the Fisher-LSD-Test considering a probability error of $\mathrm{P} \leq 0.05$. 


\section{Results}

During the rearing period in the commercial fish farm mortality rates of $0.17 \%$ and $0.19 \%$ were determined for the diploid and triploid rainbow trout, respectively.

The analysis of the ploidy status showed that 35 of the 40 "triploid" trout sampled after 66 weeks (T66) were triploid (87.5\%) whereas after 75 weeks $80 \%$ (32/40) of the "triploid" fishes (T75) were identified to have a triple chromosome set. All "diploid" trout after 66 and 75 weeks (D66; D75) were assessed to be diploid. The following sections only consider the results of the rainbow trout with a verified diploid and triploid ploidy status.

All rainbow trout slaughtered in the presented study had a gonado-somatic index (GSI) of $0.1 \%$ or less. However, the GSI of the triploid trout was significantly $(\mathrm{P}<0.05)$ lower $(0.03 \%)$ in comparison to the diploid fish $(0.1 \%)$.

During growth of the rainbow trout - independent of the ploidy status - a significant $(\mathrm{P}<0.05)$ increase of the body and fillet weights of the old animals in comparison to the young $(\mathrm{y})$ could be determined whereas the fillet yields were similar, not differing significantly $(\mathrm{P}<0.05)$. The muscle fibres of the older trout were significantly $(\mathrm{P}<0.05)$ larger not only in the dorsal fin, but also in the pelvic fin region (Tab. 1).

\section{Table 1}

LS mean and standard error values of the growth characteristics, the fillet yields and the muscle fiber diameter of samples of the dorsal and pelvic fin region of rainbow trout depending on the age (young (66 weeks), old (75 weeks)), the ploidy status (diploid (D), triploid (T)) and the interaction between the age and ploidy status (D66, T66; D75, T75) (LS-Mittel- und Standardfehler-Werte der Wachstums-Charakteristika, der Fillet-Ausbeuten und der Muskelfaser-Durchmesser von Proben aus der Rücken- und Schwanzflossen-Region von Regenbogenforellen in Abhängigkeit von Alter (jung (66 Wochen), alt (75 Wochen)), Ploidiestatus (diploid (D), triploid (T)) und der Interaktion zwischen Alter und Ploidiestatus (D66, T66; D75, T75))

\begin{tabular}{|c|c|c|c|c|c|c|c|c|}
\hline & $\begin{array}{c}\text { Young } \\
(66 \\
\text { weeks }) \\
(\mathrm{N}=75)\end{array}$ & $\begin{array}{c}\text { Old } \\
(75 \\
\text { weeks }) \\
(\mathrm{N}=72)\end{array}$ & $\begin{array}{l}\text { Diploid } \\
\text { (D) } \\
(\mathrm{N}=80)\end{array}$ & $\begin{array}{l}\text { Triploid } \\
\text { (T) } \\
(\mathrm{N}=67)\end{array}$ & $\begin{array}{c}\text { D66 } \\
(\mathrm{N}=40)\end{array}$ & $\begin{array}{c}\text { T66 } \\
(\mathrm{N}=35)\end{array}$ & $\begin{array}{c}\text { D75 } \\
(\mathrm{N}=40)\end{array}$ & $\begin{array}{c}\mathrm{T} 75 \\
(\mathrm{~N}=32)\end{array}$ \\
\hline Body weight [g] & $\begin{array}{l}251.3^{\mathrm{a}} \\
\pm 6.5\end{array}$ & $\begin{array}{c}401.1^{\mathrm{b}} \\
\pm 6.9\end{array}$ & $\begin{array}{l}311.7^{\mathrm{a}} \\
\pm 6.44\end{array}$ & $\begin{array}{c}340.7^{\mathrm{b}} \\
\pm 6.9\end{array}$ & $\begin{array}{l}239.7^{\mathrm{a}} \\
\pm 8.9\end{array}$ & $\begin{array}{c}263.0^{\mathrm{a}} \\
\pm 9.5\end{array}$ & $\begin{array}{c}383.8^{\mathrm{a}} \\
\pm 9.3\end{array}$ & $\begin{array}{l}418.5^{b} \\
\pm 10.1\end{array}$ \\
\hline Fillet weight [g] & $\begin{array}{c}148.8^{\mathrm{a}} \\
\pm 4.6\end{array}$ & $\begin{array}{c}239.7^{\mathrm{b}} \\
\pm 4.8\end{array}$ & $\begin{array}{l}177.0^{\mathrm{a}} \\
+4.5\end{array}$ & $\begin{array}{c}211.7^{\mathrm{b}} \\
\pm 4.9\end{array}$ & $\begin{array}{c}134.8^{\mathrm{a}} \\
\pm 6.2\end{array}$ & $\begin{array}{c}162.7^{\mathrm{b}} \\
\pm 6.7\end{array}$ & $\begin{array}{c}219.2^{\mathrm{a}} \\
\pm 6.5\end{array}$ & $\begin{array}{c}260.7^{\mathrm{b}} \\
\pm 7.1\end{array}$ \\
\hline Fillet yield [\%] & $\begin{array}{l}58.8^{\mathrm{a}} \\
\pm 0.9\end{array}$ & $\begin{array}{l}60.4^{\mathrm{a}} \\
\pm 0.9\end{array}$ & $\begin{array}{l}56.5^{\mathrm{a}} \\
\pm 0.9\end{array}$ & $\begin{array}{l}62.7^{\mathrm{b}} \\
\pm 0.9\end{array}$ & $\begin{array}{l}56.0^{\mathrm{a}} \\
\pm 1.2\end{array}$ & $\begin{array}{l}61.6^{\mathrm{b}} \\
\pm 1.3\end{array}$ & $\begin{array}{l}57.0^{\mathrm{a}} \\
\pm 1.3\end{array}$ & $\begin{array}{l}63.7^{\mathrm{b}} \\
\pm 1.4\end{array}$ \\
\hline $\begin{array}{l}\text { Diameter of the } \\
\text { white fibres of the } \\
\text { dorsal fin region } \\
{[\mu \mathrm{m}]}\end{array}$ & $\begin{array}{l}93.2^{\mathrm{a}} \\
\pm 1.0\end{array}$ & $\begin{array}{l}97.9^{b} \\
\pm 1.1\end{array}$ & $\begin{array}{l}90.1^{\mathrm{a}} \\
\pm 1.0\end{array}$ & $\begin{array}{c}101.1^{\mathrm{b}} \\
\pm 1.1\end{array}$ & $\begin{array}{l}89.5^{\mathrm{a}} \\
\pm 1.4\end{array}$ & $\begin{array}{l}96.9^{b} \\
\pm 1.5\end{array}$ & $\begin{array}{l}90.7^{\mathrm{a}} \\
\pm 1.5\end{array}$ & $\begin{array}{c}105.2^{b} \\
\pm 1.6\end{array}$ \\
\hline $\begin{array}{l}\text { Diameter of the } \\
\text { white fibres of the } \\
\text { pelvic fin region } \\
{[\mu \mathrm{m}]}\end{array}$ & $\begin{array}{l}92.1^{\mathrm{a}} \\
\pm 1.1\end{array}$ & $\begin{array}{l}95.4^{\mathrm{b}} \\
\pm 1.1\end{array}$ & $\begin{array}{l}89.3^{\mathrm{a}} \\
\pm 1.1\end{array}$ & $\begin{array}{l}98.3^{b} \\
\pm 1.1\end{array}$ & $\begin{array}{l}87.4^{\mathrm{a}} \\
\pm 1.5\end{array}$ & $\begin{array}{l}96.8^{\mathrm{b}} \\
\pm 1.6\end{array}$ & $\begin{array}{l}91.1^{\mathrm{a}} \\
\pm 1.5\end{array}$ & $\begin{array}{l}99.8^{\mathrm{b}} \\
\pm 1,7\end{array}$ \\
\hline
\end{tabular}

a.b.c Mean values with different superscripts within a line differ significantly $(\mathrm{P}<0.05)$ between the age (young, old), ploidy status (diploid (D), triploid (T)) or the interaction between the age and ploidy status (D66 vs. T66; D75 vs. T75).

Considering the ploidy status the triploid fish $(\mathrm{T})$ had significantly $(\mathrm{P}<0.05)$ higher properties in the investigated growth characteristics body and fillet weight, fillet yield 
and muscle fibre diameters in the dorsal and pelvic fin region in comparison to the diploid (D) animals (Tab. 1).

Comparing the growth and fibre characteristics in the groups of the young (D66; T66) and old diploid and triploid rainbow trout (D75; T75) the fillet weights and yields as well as the fibre diameters in the dorsal and pelvic fin region of T66 and T75 were significantly $(\mathrm{P}<0.05)$ higher in comparison to the D66 and D75. With regard to the body weights significant differences could only be found in the old trout but not in the young (Tab. 1).

Additionally to the growth properties quality aspects like the nutritional value, the colour and the water-holding capacity (WHC) of the fish fillets are important characteristics for consumers and processors. The characterisation of the muscle-tomeat-transition process by determining the $\mathrm{pH}$ and electrical conductivity (EC) development in the trout fillet after slaughter is also an important factor as it might have an influence on the parameters colour or WHC.

As shown in Table 2 the old rainbow trout $(0)$ had significantly $(\mathrm{P}<0.05)$ lower early $\left(\mathrm{pH}_{1}\right)$ and late postmortal $\mathrm{pH}\left(\mathrm{pH}_{3}\right)$ values in comparison to the young animals $(\mathrm{y})(\mathrm{y}$ : $\mathrm{pH}_{1}=6.94, \mathrm{pH}_{3}=6.84 ; \underline{\mathrm{o}}$ : $\left.\mathrm{pH}_{1}=6.83, \mathrm{pH}_{3}=6.71\right)$. The $\mathrm{EC}_{1}$-values were significantly $(\mathrm{P}<0.05)$ higher in the older trout whereas the late $\mathrm{EC}\left(\mathrm{EC}_{3}\right)$ did not show great difference ( $\mathrm{P}>0.05$ ) (Tab. 2). With regard to the colour values the old trout fillets were significantly $(\mathrm{P}<0.05)$ brighter and more red and yellow than the fillets of the younger animals. The $\mathrm{Q}$-values decreased significantly $(\mathrm{P}<0.05)$ during ageing from 0.74 in the young fish to 0.71 in the old animals indicating a reduction in the WHC.

Considering the ploidy status - presented in Table 2 - the diploid trout (D) had significantly $(\mathrm{P}<0.05)$ lower $\mathrm{pH}$-values shortly after slaughter $\left(\mathrm{pH}_{1}\right)$ whereas the late $\mathrm{pH}\left(\mathrm{pH}_{3}\right)$ was did not differ significantly $(\mathrm{P}>0.05)$ between the genetics. The ECvalues differ only significantly $(\mathrm{P}<0.05)$ shortly after slaughter of the diploid and triploid rainbow trout. The analysis 3 hours after slaughter resulted in similar ECvalues not differing significantly $(\mathrm{P}>0.05)$ between the investigated genetics. The determination of the colour showed that the fish fillets of the diploid trout were darker than the triploid fish, whereas the redness and yellowness-values did not show great difference $(\mathrm{P}>0.05)$. Considering the WHC the triploid trout had significantly lower Qvalues $(\mathrm{Q}=0.65)$ than the diploid fish $(\mathrm{Q}=0.80)$.

Comparing the meat characteristics in the groups of the young (D66; T66) and old diploid and triploid rainbow trout (D75; T75) - as presented in Table 2 - the young trout had comparable $\mathrm{pH}_{1}$-values whereas the late $\mathrm{pH}_{3}$-values differed significantly $(\mathrm{P}<0.05)$ between D66 and T66. In contrast to this, D75 had not only significantly $(\mathrm{P}<0.05)$ lower $\mathrm{pH}_{1^{-}}$, but also reduced $\mathrm{pH}_{3}$-values in comparison to the T75. The $\mathrm{EC}_{1^{-}}$ values of the young and old triploid trout were generally higher than the values of the diploid fish. The determination of the EC $3 \mathrm{~h}$ after slaughter $\left(\mathrm{EC}_{3}\right)$ resulted in significantly $(\mathrm{P}<0.05)$ higher values in the younger triploid trout $(\mathrm{D} 66: 2.3 \mathrm{mS} / \mathrm{cm}$; T66: $3.3 \mathrm{mS} / \mathrm{cm}$ ) whereas in the older trout the values differ also significantly $(\mathrm{P}<0.05)$ but vice versa (D75: $3.3 \mathrm{mS} / \mathrm{cm}$; T75: $2.1 \mathrm{mS} / \mathrm{cm})$. The Q-values - an indication of the WHC of the fillets - were significantly $(\mathrm{P}<0.05)$ lower not only in the $\mathrm{T} 66(\mathrm{Q}=0.64)$, but also the $\mathrm{T} 75(\mathrm{Q}=0.66)$ in comparison to the diploid trout (D66: $\mathrm{Q}=$ 0.85; D75: $\mathrm{Q}=0.76)(\mathrm{Tab} .2)$. 


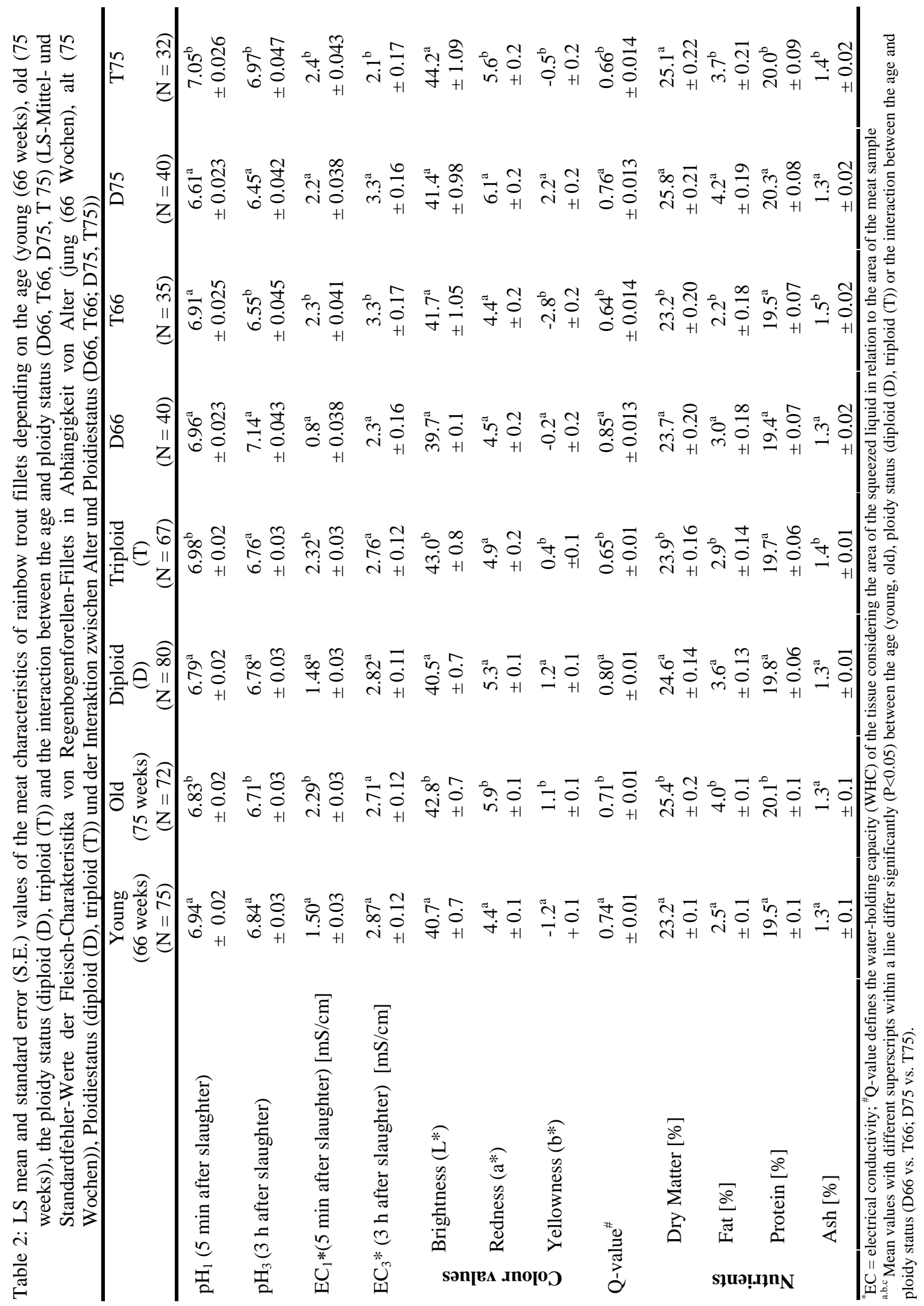


The nutrient analysis of the trout fillet showed that the older rainbow trout had significantly $(\mathrm{P}<0.05)$ higher dry matter $(25.4 \%)$, fat $(4.0 \%)$ and protein concentration (20.1\%) in comparison to the young fish $(23.2 \%, 2.5 \%, 19.5 \%$, respectively). Only the ash contents did not differ significantly between the groups ( $\mathrm{P}>0.05$ ) (Tab. 2).

Considering the ploidy status of the investigated trout it could be shown that the fillets of the triploid $(\mathrm{T})$ trout had significantly $(\mathrm{P}<0.05)$ lower dry matter $(23.9 \%)$ and fat contents $(2.9 \%)$ but significantly $(\mathrm{P}<0.05)$ higher ash concentrations $(1.4 \%)$ than the diploid (D) fish (24.6\%, $3.6 \%, 1.3 \%$, respectively). Only the protein concentrations of the fillets were comparable ( $\mathrm{D}=19.8 \%$; $\mathrm{T}=19.7 \%$ ) (Tab. 2).

Comparing the nutrient concentration of the fillets in the groups of the young (D66; T66) and old diploid and triploid rainbow trout (D75; T75) in the younger group the differecnes were identical with the results described in the previous chapter, with significantly $(\mathrm{P}<0.05)$ lower dry matter $(23.2 \%)$ and fat $(2.2 \%)$ but higher ash concentrations (1.5\%) in the young triploids (T66) in comparison to the D66 (23.7\%, $3.0 \%, 1.3 \%$, respectively). In the older trout significant differences $(\mathrm{P}<0.05)$ could be only determined with regard to the fat $(\mathrm{D} 75=4.2 \%$, T75 $=3.7 \%)$ and ash concentrations (D75 $=1.3 \%$, T75 $=1.4 \%$ ). However, in the older group the protein concentrations $(\mathrm{D} 75=20.3 \%$, T75 $=20.0 \%)$ differ significantly $(\mathrm{P}<0.05)$ whereas the dry matter content $(\mathrm{D} 75=25.8 \%$, T75 $=25.1 \%$ ) did not differ significantly $(\mathrm{P}>0.05)$.

\section{Discussion}

The low mortality rates of the triploid trout in the presented study are contradictory to other studies in salmonids (SOLAR et al., 1984; LINCOLN and BYE, 1984; TIWARY et al., 2004) that presented higher percentages of dead triploid animals mainly at earlier development periods. A reason for this difference might be that in the present study only the mortality rates between week 41 to 75 were recorded and that the mortality rates were probably higher before week 41 . However, the inferiority of triploids at earlier developmental stages should be considered but is neglectable in comparison to the advantages of triploid at later growth periods -especially during maturation (THORGAARD, 1992).

The advantageous growth properties of the triploid rainbow trout - presented in the study - are difficult to discuss because other investigations found that $\mathrm{T}$ trout grow similar or inferior in comparison to immature D fish (SOLAR et al., 1984; THORGAARD, 1992; SURESH and SHEEHAN, 1998; TEUSCHER et al., 2003). A maturation-related impact on the growth seems unlikely because all animals had rather small gonads and low GSI values and female rainbow trout usually mature not before an age of 2-3 years (MARTYNIUK et al., 2003). A genetic difference could be also excluded as the eggs of the rainbow trout came from the same breeding company and had the same genetic origin. The eggs were randomly selected for triploidy induction. Considering a heritability $\mathrm{h}^{2}$ for the growth properties of 0.55 to 0.72 (FISHBACK et al., 2002) an environmental influence on the presented results should be also considered. In the present study we decided to rear the diploid and triploid rainbow trout in different basins side by side at comparable environmental conditions. The water that flew through both basins had the same temperature, $\mathrm{pH}$ and oxygen concentrations. The animals were fed with the same feed. The different genetics were separated during growth because it has been described that triploid rainbow trout 
might have a different physiological competence - e.g. concerning the stress response or swimming capacity (VIRTANEN et al., 1990; OJOLICK et al., 1995; SURESH and SHEEHAN, 1998; BENFEY, 1999; LEGATT et al., 2006) and that the production of diploid and triploid rainbow trout in one basin might have a negative influence on one of the genetic. A direct interaction possibly affects the feed entry and consumption. However, further investigations are necessary to clarify the impact of the environment on the growth development especially under common rearing conditions.

The presented differences of the muscle fibre diameters agree with other investigations in rainbow trout (SURESH and SHEEHAN, 1998) and in Atlantic salmon (SIGURGISLADOTTIR et al., 2001; BJOERNEVIK et al., 2004). In contrast to this JOHNSTON et al. (1999) found no clear differences of the fibre diameters in female triploid and diploid Atlantic salmon of the same body length. Triploids have larger cells because the cells contain three sets of chromosomes and more DNA and the increased nuclear volume corresponds with an increase in cellular volume (BENFEY and SUTTERLIN, 1984; BJOERNEVIK et al., 2004). It could be suggested that the higher fillet weights of the triploid trout are related to the generally higher cellular volume.

The pre-mortem conditions which alter the physiology of the fish have an impact on the post-mortem muscle biochemistry (e.g. pH or EC development) and this could influence the quality of the fish fillets- for example the colour, texture or WHC (JOHNSTON et al., 1999; THOMAS et al., 1999; GIUFFRIDA et al., 2007). Exercise or stress before slaughter results in an accelerated decrease of the $\mathrm{pH}$ due to higher lactate production in the muscle tissue (THOMAS et al., 1999; MORZEL et al., 2003, GIUFFRIDA et al., 2007). The age- or ploidy-related effects on the $\mathrm{pH}$ - and EC development - presented in the study - could be either related to a different response to pre-slaughter stress or exercise, and /or to a difference in the muscle characteristics that influence the muscle-to-meat transition. However, the presented differences of the $\mathrm{pH}$ and EC values either between the young and old, or the diploid and triploid rainbow trout as well as between the D66 and T66 or D75 and T75 are difficult to discuss. Investigations in fish (FAUCONNEAU et al., 1995; PERIAGO et al., 2005) and in mammalian species like pig (REHFELDT et al., 2004) showed that animals with larger muscle fibres seem to be more susceptible to stress or exercise before slaughter because these animals are not sufficiently able to compensate the stressrelated increase in the cell metabolism - especially in the oxygen consumption probably resulting in increasing anaerobic glycolysis and lactacidosis. The rapid $\mathrm{pH}$ decline forces the leak of water from the muscle cells thereby increasing the EC-values and reducing the WHC. The differences of the $\mathrm{pH}$ - and EC-values between the younger and older trout could be explained by the larger muscle fibres in the older animals. Considering the ploidy status of the trout the differences of the EC values could be also related to the muscle characteristics. However, the alteration of the $\mathrm{pH}$ values in the diploid and triploid trout contradict the previous assumption suggesting that either the ploidy status of the animals affects the $\mathrm{pH}$ characteristics independent of the muscle structure, or the $\mathrm{pH}$ results are random. Further investigations are necessary to clarify the ploidy dependent effect of the $\mathrm{pH}$ reduction after slaughter.

The determination of the amount of expressible moisture (Q-value) as an indicator of the WHC resulted in a significantly $(\mathrm{P}<0.05)$ lower WHC in the older and in the (young and old) triploid trout. Although the WHC has not been investigated in fish 
muscles it could be suggested that the reduced WHC is significantly affected by the larger muscle fibres of the older as well as the (young and old) triploid trout. The negative effect of large muscle fibres on the WHC could be related to the higher metabolic susceptibility of the hypertrophic fibres to stress or exercise - already described in the previous chapter - accompanied with lactacidosis, protein denaturation, cell desintegration and a reduced capacity of the cell systems to bind water. This assumption is supported by comparable results in pigs (REHFELDT et al., 2004).

Considering the colour of the fillets the increase of the $\mathrm{L}^{*}$-values with regard to the age and ploidy status might be again related to the fibre size in the muscle tissue. This assumption is supported by investigations in Atlantic salmon (JOHNSTON et al., 2000) or mammalian species like pig (REHFELDT et al., 2004). The increase in the fibre size during ageing reduces the mitochondria content and thereby the concentration of the heme-subunits of the myoglobin increasing the brightness of the tissue. The differences in the redness and yellowness values of the fillets between the young and old as well as the diploid and triploid trout seem to be more influenced by the feeding of the animals. Astaxanthin is a naturally occurring carotenoid pigment that is commonly used in salmonid feed to improve the colour appearance of the flesh. The pigment is water insoluble and usually deposited in the intramuscular fat tissue (LOOKWOOD et al., 2003). It could be suggested that in the older trout the longer astaxanthin intake and in the older as well as the (young and old) diploid trout the higher fat concentration in the fillets (Tab. 2) resulted in the redder and more yellow colour appearance of the fillets (JOHNSTON et al., 2000; DILER et al., 2004).

The results of the fillet composition analysis with a higher fat and protein concentration in the older rainbow trout are in accordance with other investigations in fish (KAUSE et al., 2002; BJOERNEVIK et al., 2004). A reason for this age-related increase in the proximate parameters fat and protein might be the change from mainly active-growing to passive-maintenance metabolism influenced by reduced motility and inadequate feeding of the animals. However, the increase in the nutrient content is a positive effect considering the nutritional value of the fish fillets especially after processing. With regard to the ploidy status of the trout the lower fat and partly reduced protein concentration in the fillets of the triploid fish contradicts the results by KAUSE et al. (2002) who presented a relationship between fillet weight and its fat and protein concentration. It could be suggested that the increased hypertrophy in the $\mathrm{T}$ is mainly related to higher water accumulation in the muscle tissue accompanied with a general reduction in the dry matter and especially the fat and partly the protein concentration. This assumption would also explain the generally lower WHC in the triploid fillets.

The presented results show that during ageing of female rainbow trout the increase of the body and fillet weights takes place by muscle fibre hypertrophy. This alteration seems to be accompanied by partly unwanted effects on the flesh quality like increased brightness and EC development as well as reduced WHC. Considering the ploidy status the higher body and fillet weights of the triploid trout mainly due to increasing muscle fibre diameters are accompanied with partly negative effects on the flesh quality - higher brightness and reduced WHC - and the nutritional value of the fillets with lower dry matter and fat contents. It could be concluded that the use of triploid rainbow trout before onset of maturation can have a positive effect on the profit due to 
the better growth characteristics but the farmer has to consider poorer flesh qualities and nutritional values of the larger fillets.

\section{Acknowledgements}

Many thanks to the colleagues in Vechta and Goettingen for the help in the preparation of the rainbow trout and the realisation of the analyses. A special thank to the Ternaeben Service GmbH, Lembruch, Germany, for the financial support of the study.

\section{References}

AOAC:

Official methods of analysis of the association of official analytical chemists. $\left(14^{\text {th }}\right.$ Ed.) Association of official analytical chemists. Arlington VA., 1984

BENFEY, T.J.; SUTTERLIN, A.M.:

The Hematology of Triploid Landlocked Atlantic Salmon, Salmo-Salar l. J. Fish Biol. 24 (1984), 333338

BENFEY, T.J.:

The Physiology and Behavior of Triploid Fishes. Reviews in Fisheries Science 7 (1999), 39-67

BJORNEVIK, M.; ESPE, M.; BEATTIE, C.; NORTVEDT, R.; KIESSLING, A.:

Temporal variation in muscle fiber area, gaping, texture, colour and collagen in triploid and diploid atlantic salmon (Salmo salar L). J. Sci. Food Agric. 84 (2004), 530-540

CHOURROUT, D.:

Pressure-induced retention of second polar body and suppression of first cleavage in rainbow trout: production of all-triploids, all-tetraploids, and heterozygous and homozygous diploid gynogenetics. Aquaculture 36 (1984), 111-126

DILER, I.; GOKOGLU, N.:

Investigation of the sensory properties of the flesh of rainbow trout (Oncorhynchus mykiss) fed diets with astaxanthin, shrimp waste meal and red pepper meal. Europ. Food Res. Technol. 219 (2004), 217222

FAUCONNEAU, B.;ALAMIDURANTE, H.;LAROCHE, M.;MARCEL, J.;VALLOT, D.:

Growth and Meat Quality Relations in Carp. Aquaculture 129 (1995), 265-297

FISHBACK, A.G.; DANZMANN, R.G.; FERGUSON, M.M.; GIBSON, J.P.:

Estimates of genetic parameters and genotype by environment interactions for growth traits of rainbow trout (Oncorhynchus mykiss) as inferred using molecular pedigrees. Aquaculture 206 (2002), 137-150

GEYIKOGLU, F.; VURALER, Ö.; TEMELLI, A.:

Histological, histochemical and ultrastructural investigations on the esophagus of juvenile rainbow trout (Oncorhynchus mykiss). Turk.. J. Zool. 28 (2004), 73-82

GIUFFRIDA, A.; PENNISI, L.; ZIINO, G.; FORTINO, L.; VALVO, G.; MARINO, S.; PANEBIANCO, A.: Influence of Slaughtering Method on Some Aspects of Quality of Gilthead Seabream and Smoked Rainbow Trout. Vet. Res. Comm. 31 (2007), 437-446

HUNTER, G.A.; DONALDSON, E.M.: Hormonal sex control and its application to fish culture. Fish Physiol. 9 (1983), 223-303

HUNTER, G. A.; DONALDSON, E. M.; STOSS, J.; BAKER, I.:

Production of monosex female groups of chinook salmon (Oncorhynchus tshawytscha) by the fertilization of normal ova with sperm from sex-reversed females. Aquaculture 33 (1983), 355-364

JOHNSTON, I.A.; WARD, P.S.; GOLDSPINK, G.:

Studies on the swimming musculature of the rainbow trout: I. Fibre types. J. Fish Biol. 1 (1975), 451458

JOHNSTON, I.A.; STRUGNELL, G.; MCCRACKEN, M.L.; JOHNSTONE, R.:

Muscle growth and development in normal-sex-ratio and all-female diploid and triploid Atlantic salmon. J. Exp. Biol. 202 (1999), 1991-2016

JOHNSTON, I.A.; ALDERSON, R.; SANDHAM, C.; DINGWALL, A.; MITCHELL, D.; SELKIRK, C.;

NICKELL, D.; BAKER, R.; ROBERTSON, B.; WHYTE, D.; SPRINGATE, J.:

Muscle fibre density in relation to the colour and texture of smoked Atlantic salmon (Salmo salar L.). Aquaculture 189 (2000), 335-349

KAUSE, A.; RITOLA, O.; PAANANEN, T.; MANTYSAARI, E.; ESKELINEN, U.:

Coupling body weight and its composition: a quantitative genetic analysis in rainbow trout. Aquaculture 211 (2002), 65-79

KIESSLING, A.; RUOHONEN, K.; BJøRNEVIK, M.: 
Muscle fibre growth and quality in fish. Arch. Tierz., Dummerstorf 49 (2006) Special Issue, 137-146

LEGGATT, R.A.; SCHEER, K.W.; AFONSO, L.O.B.; IWAMA, G.K.:

Triploid and diploid rainbow trout do not differ in their stress response to transportation. North American Journal of Aquaculture 68 (2006), 1-8

LINCOLN, R. F.; AULSTAD, D.; GRAMMELT, A.:

Attempted Triploid Induction in Atlantic Salmon (Salmo-Salar) Using Cold Shocks. Aquaculture 4 (1974), 287-297

LINCOLN, R. F.; SCOTT, A.P.:

Production of All-Female Triploid Rainbow-Trout. Aquaculture 30 (1983), 375-380

LINCOLN, R.F.; BYE, V.J.:

Triploid rainbows show commercial potential. Fish. Farmer 7 (1984), 30-32

LOOKWOOD, S.F.; O`MALLEY, S.; MOSHER, G.L.:

Improved aqueous solubility of crystalline astaxanthin (3,3`-dihydroxy-ß, ß-carotene-4,4`-dione) by Captisol ${ }^{\circledR}$ (Sulfobutyl Ether ß-Cyclodextrin). J. Pharmacol. Sci. 92 (2003), 922-926

MARTYNIUK, C.J.; PERRY, G.M.L.; MOGAHADAM, H.K.; FERGUSON, M.M.; DANZMANN, R.G.:

The genetic architecture of correlations among growth-related traits and male age at maturation in rainbow trout. J. Fish Biol. 63 (2003), 746-764

MEYER, J.N.; HOERSTGEN-SCHWARK, G.; KIM, B.C.; FRICKE, H.:

Wasserbindungsvermögen im Forellenmuskel. Z. Tierzücht. Züchtungsbiol. 101 (1984), 389-393

MORZEL, M.; SOHIER, D.; VAN DE VIS, H.:

Evaluation of slaughtering methods for turbot with respect to animal welfare and flesh quality. J. Sci. Food Agric. 83 (2003), 19-28

MUELLER-BELECKE, A.; GEBHARDT, S.; WERNER, C.; POONTAWEE, K.; WICKE, M.; HOERSTGENSCHWARK, G.:

Comparison of growth and carcass composition of diploid and triploid pan-size rainbow trout (Oncorhynchus mykiss). Züchtungskunde 78 (2006), 129-135

OJOLICK, E.J.; CUSACK, R.; BENFEY, T.J.; KERR, S.R.:

Survival and Growth of All-Female Diploid and Triploid Rainbow-Trout (Oncorhynchus-Mykiss) Reared at Chronic High-Temperature. Aquaculture 131 (1995), 177-187

PERIAGO, M.J.; AYALA, M.D.; LOPEZ-ALBORS, O.; ABDEL, I.; MARTINEZ, C.; GARCIA-ALCAZAR, A.; ROS, G.; GIL, F.:

Muscle cellularity and flesh quality of wild and fanned sea bass, Dicentrarchus labrax L. Aquaculture 249 (2005), 175-188

PHILLIPS, R.B.; ZAJICEK, K.D.; IHSSEN, P.E.; JOHNSON, O.: Application of silver staining to the identification of triploid fish cells. Aquaculture 54 (1986), 313-319

QUILLET, E.:

Survival, growth and reproductive traits of mitotic gynogenetic rainbow trout females. Aquaculture 123 (1984), 223-236

REHFELDT, C.; FIEDLER, I.; STICKLAND, N.C.:

Number and size of muscle fibres in relation to meat production, in Muscle development of livestock animals, physiology, genetics and meat quality, ed. by te Pas MFW, Everts ME, Haagsman HP, CABI Publishing, UK, p. 1-38 (2004)

SIGURGISLADOTTIR, S.; SIGURDARDOTTIR, M.S.; INGVARSDOTTIR, H.; TORRISSEN, O.J.; HAFSTEINSSON, H.:

Microstructure and texture of fresh and smoked Atlantic salmon, Salmo salar L., fillets from fish reared and slaughtered under different conditions. Aquaculture Res. 32 (2001), 1-10

SOLAR, I. I.; DONALDSON, E. M.; HUNTER, G. A.: Induction of Triploidy in Rainbow-Trout (Salmo-Gairdneri Richardson) by Heat-Shock, and Investigation of Early Growth. Aquaculture 42 (1984), 57-67

StatSoft, Inc: STATISTICA für Windows [Software-System für statistical data analysis] Version 7.1 (2005)

SURESH, A.V.; SHEEHAN, R.J.: Muscle fibre growth dynamics in diploid and triploid rainbow trout. J. Fish Biol. 52 (1998), 570-587

TEUSCHER, D.M.; SCHILL, D.J.; MEGARGLE, D.J.; DILLON, J.C.: Relative survival and growth of triploid and diploid rainbow trout in two Idaho reservoirs. North Am. J. Fish. Manag. 23 (2003), 983-988

THOMAS, P.M.; PANKHURST, N.W.; BREMNER, H.A.:

The effect of stress and exercise on post-mortem biochemistry of Atlantic salmon and rainbow trout. J. Fish Biol. 54 (1999), 1177-1196

THORGAARD, G.H.:

Application of genetic techniques to rainbow trout. Aquaculture 100 (1992), 85-97 
TIWARY, B.K.; KIRUBAGARAN, R.; RAY, A.K.:

The biology of triploid fish. Rev. Fish. Biol. Fisher. 14 (2004), 391-402

VIRTANEN, E.; FORSMAN, L.; SUNDBY, A.:

Triploidy Decreases the Aerobic Swimming Capacity of Rainbow-Trout (Salmo-Gairdneri). Comp. Biochem. Physiol. A. 96 (1990), 117-121

Received: 2007-09-10

Accepted: 2007-10-08

Corresponding Author Dr. CARSTEN WERNER

Institut für Tierzucht, Fakultät für Agrarwissenschaften, Georg-August-Universität Göttingen

Albrecht-Thaer-Weg 3

37075 GÖTTINGEN, GERMANY 